\title{
What We Teach When We Teach German Constitutional Law: An Introduction to the Collection Memorializing Donald P. Kommers
}

By Russell A. Miller*

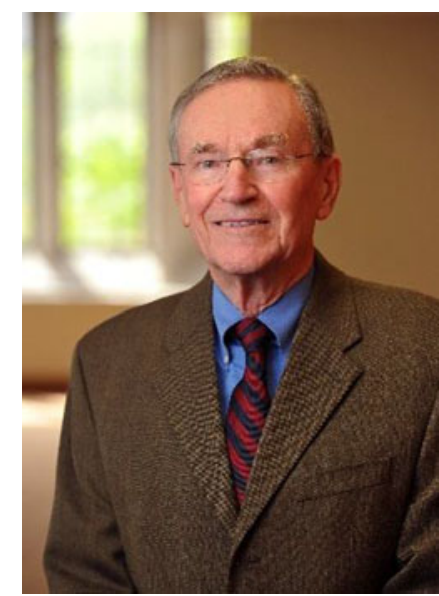

Donald P. Kommers ${ }^{\dagger}$ (1932-2018)

Photo Credit Matt Cashore, University of Notre Dame

\section{A. Introduction}

My German colleagues sometimes express surprise when they learn that I lead an annual seminar on German constitutional law at my American law school. "Are American students really interested in German law," they ask with incredulity. This may be a case of coy self-satisfaction. Or is it a well-deserved dig at American parochialism and constitutional exceptionalism? In truth, it is the question that is surprising. Germany has a prominent place in comparative constitutional law's canon, and German constitutional law has achieved particularly high standing in American comparative law teaching. In comparative constitutional law courses and seminars, for example, students regularly read the German Constitutional Court's Abortion I Case ${ }^{1}$

${ }^{\star}$ J.B. Stombock Professor of Law, Washington \& Lee University School of Law.

${ }^{\dagger}$ Joseph and Elizabeth Robbie Professor of Political Science University of Notre Dame Law School / Department of Political Science.

${ }^{1}$ Bundesverfassungsgericht [BVERFG] [Federal Constitutional Court] Feb. 25, 1975, 39 ENTSCHEIDUNGEN DES BundESVERFASSUNGSGERICHTS [BVERFGE] 1, 1975 (Ger.).

(C) 2019 The Author. Published by Cambridge University Press on behalf of the German Law Journal. This is an Open Access article, distributed under the terms of the Creative Commons Attribution licence (http://creativecommons.org/licenses/by/4.0/), which permits unrestricted re-use, distribution, and reproduction in any medium, provided the original work is properly cited. 
alongside the U.S. Supreme Court's decision in Roe v. Wade. ${ }^{2}$ Vicki Jackson and Mark Tushnet feature thirteen translations of German Federal Constitutional Court decisions in their groundbreaking American law school casebook Comparative Constitutional Law. ${ }^{3}$ Only the United States Supreme Court, with sixteen featured cases, attracts more attention. The other major comparative constitutional law casebook in the American market, Comparative Constitutionalism, features three times as many German cases, a focus no doubt facilitated by the fact that German Federal Constitutional Court Justice Susanne Baer is one of the book's co-authors. ${ }^{4}$

\section{B. Donald Kommers' American-German Constitutional Law}

Americans' interest in German constitutional law can be traced to a single source. Donald Kommers, the political scientist and legal scholar at Notre Dame, pioneered the field of comparative constitutional law and popularized German constitutional jurisprudence in the Englishspeaking world with his groundbreaking study of the German Federal Constitutional Court, ${ }^{5}$ and his seminal, English-language treatise on German constitutional law that first published in 1989. ${ }^{6}$ The previously mentioned comparative constitutional law casebooks republish several of Kommers' translations of the Federal Constitutional Court's cases. I also have been told that many American comparatists teach from Kommers' treatise, which possesses the functional title The Constitutional Jurisprudence of the Federal Republic of Germany. ${ }^{7}$ The book's original commentary on German constitutional law is illustrated with translated excerpts from scores of decisions from the German Federal Constitutional Court.

German constitutional law's American success, based as it is on Kommers' work, nevertheless exposes some dramatic differences in the way German constitutional law is taught in America and Germany.

To begin, there likely isn't even a course in a German law school curriculum called Verfassungsrecht (constitutional law). Instead, Germans are introduced to their system's constitutional precepts and principles in a series of courses entitled Staatsrecht (state law). The focus of these courses is the Basic Law, ${ }^{8}$ and European Union law if a third semester is required. ${ }^{9}$ But the name of these courses, with the priority it places on the state, which is seen as preceding and superseding the constitution, suggests that Americans and Germans are in different theoretical and pedagogical places when they teach constitutional law. ${ }^{10}$

More profoundly, Americans almost exclusively teach German constitutional law from Kommers' case translations. His work, and our teaching from the Federal Constitutional Court's opinions, align German constitutional law with the American case method and its roots in the common law. But that is not how German constitutional law is done in Germany. Like other fields of law, German law students encounter German constitutional law through the

\footnotetext{
${ }^{2}$ Roe v. Wade, 410 U.S. 113 (1973).

${ }^{3}$ Vicki C. JaCKSON \& Mark Tushnet, Comparative Constitutional LaW ( $3^{\text {rd }}$ ed. 2014).

${ }^{4}$ Norman Dorsen et al., Comparative Constitutionalism ( $3^{\text {rd }}$ ed. 2016).

${ }^{5}$ Donald P. Kommers, Judicial Politics in West Germany (1976).

${ }^{6}$ See Donald P. Kommers, The Constitutional Jurisprudence of the Federal Republic of Germany (1989).

${ }^{7} \mathrm{I}$ joined Kommers as a co-author of the book's third edition. See Donald P. Kommers \& Russell A. Miller, The Constitutional Jurisprudence of the Federal Republic of Germany ( $3^{\text {rd }}$ ed. 2012).

${ }^{8}$ The typical textbooks and exam-preparation materials use the term Staatsrecht. See, e.g., ChristopH DEGENHART, StaAtsrecht I - StaAtsorganisationsrecht (27 ${ }^{\text {th }}$ ed. 2011); Thorsten Kingreen \& Ralf Poscher, Grundrechte -

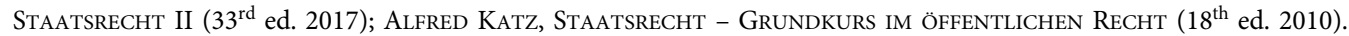

${ }^{9}$ See, e.g., Heiko Sauer, StaAtsrecht III - Auswärtige Gewalt, BezÜge des Grundgesetzes Zu VölKer- UND EUROPARECHT (5 $5^{\text {th }}$ ed. 2018).

${ }^{10} \mathrm{See}$, e.g, Jo Eric Khushal Murkens, From Empire to Union: Conceptions of German Constitutional Law Since $187169-83$ (2013).
} 
positivistic, deductive, conceptual, and dogmatic style that epitomizes German legal thinking. That tradition places a priority on legal texts and the conceptual-systematic exegesis it is given by legal scholars in sometimes sprawling commentaries. Even in constitutional law the German approach bears unmistakable elements of the continental, civilian legal mentalité ${ }^{11}$ There are some notable casebooks in the German market. ${ }^{12}$ But they chart a course through Staatsrecht that remains exceptional. Instead, German students learn the Basic Law's regime as a complex mechanism that produces constitutional results through the application of concepts and systematic analysis. It is true that some of the concepts and analyses are derived from Federal Constitutional Court's decisions. But they are learned as abstractions, and at a distance from those cases.

The gulf that exists between the case-centric German constitutional law that American comparatists teach and the dogmatic analysis that is taught in Germany has been repeatedly underscored by my encounters with German law students. I often lead them in comparative constitutional law seminars (taught in English from English-language materials) during which, inevitably and happily, I have the privilege to present the Federal Constitutional Court's seminal Lüth Case. As with my presentation of the case to my American students, that effort involves a close reading of Donald Kommers' translation of the case. ${ }^{13}$ Unfailingly the German students remark that this is the first time they have read the case, even if their studies have made them familiar with disaggregated versions of the Lüth's most prominent concepts and doctrine, including the Federal Constitutional Court's innovative conclusions about the Basic Rights' status as objektive Wertentscheidungen (objective order of values) and the Basic Rights' resulting mittelbare Drittwirkung (indirect horizontal effect) throughout the legal system. But reading Lüth also requires students to engage politically with the facts of the case, including Germany's National Socialist past, the role of art in tyrannical regimes, and the power of judges to respond to those vast problems. I sometimes show the students a clip from Viet Harlan's grotesque, anti-Semitic film Jud Sü $\beta,{ }^{14}$ before asking them whether the Federal Constitutional Court really had an alternative to its groundbreaking ruling in the case. It is a German constitutional law channeled through the American case-method and colored by American legal realism. It could not be farther from the traditional, abstract German Lösungsskizze (solution outline) through which German students engage with the case. That systematic encounter with the Lüth Case focuses on its relevance to Article 5 of the Basic Law, and it raises three basic questions: what is the Schutzbereich (scope) of Article 5; whether there has been an Eingriff (encroachment) upon that constitutional right; and whether there is a Verfassungsrechtliche Rechtfertigung (constitutional justification) for the encroachment.

American comparatists' stubborn reliance on the case-method to teach German constitutional law - a posture both facilitated and reinforced by Kommers' decision to focus his immense energies on the Federal Constitutional Court's jurisprudence and not on the scholars' legalscientific engagement with Staatsrecht - has helped produce a curious hybrid AmericanGerman constitutional law. It is a dream of the German law that is both doctrinally faithful and stylistically chimerical. Our German constitutional law is not Germany's constitutional law. It is Donald Kommers' American-German constitutional law.

\footnotetext{
${ }^{11}$ See, e.g., Russell A. Miller, Germany's German Constitution, 57 VA. J. INT'L L. 95 (2017-2018).

${ }^{12} \mathrm{See}$, e.g., CASEbook Verfassungsrecht (Christian Bumke \& Andreas Vosskuhle eds., $7^{\text {th }}$ ed. 2015).

${ }^{13} \mathrm{See}$, e.g., Justin Collings' essay in this collection.

${ }^{14}$ It was Erich Lüth's call to boycott Viet Harlan's post-war films that led to the case. Lüth was appalled that Harlan, who had directed the 1940 film Jud Süß, was returning to mainstream filmmaking.
} 


\section{A Collection Memorializing Donald Kommers}

It is the rare scholar to whom we can attribute the original invention of a new normative universe. But Donald Kommers was that rare scholar. It is with deep sorrow that we acknowledge his passing in December 2018. ${ }^{15}$

The field of comparative constitutional law lost a pioneer. German-American relations lost a steadfast bridge. Many colleagues and friends will miss him beyond words.

\footnotetext{
${ }^{15}$ See Russell Miller, German Constitutional Law's Irreplaceable Ambassador to the World, FRANKFURTER Allgemeinezeitung - EINSPRUCH MAGAZIN (Jan. 16, 2019), available at https://einspruch.faz.net/einspruch-magazin/ 2019-01-16/a54cb2674c33c0f8b5882e1f416ec910/?GEPC=s5.
}

Cite this article: Miller RA (2019). What We Teach When We Teach German Constitutional Law: An Introduction to the Collection Memorializing Donald P. Kommers. German Law Journal 20, 514-517. https://doi.org/10.1017/glj.2019.35 